\title{
Management of Food Security Projects in Vulnerable Communities in the Department of Bolivar - Colombia
}

\author{
Piedad M. Montero ${ }^{\# 1}$, Diofanor Acevedo Correa ${ }^{\# 2}$, Raúl J. Martelo ${ }^{\# 3}$ \\ ${ }^{\#}$ Faculty of Engineering, Food Engineering program, Research Group NUSCA, University of Cartagena \\ Av. El Consulado, St. 30 No. 48-152. Cartagena de Indias, Colombia. \\ * Faculty of Engineering, Research Group in Communications and Informatics Technologies GIMATICA. \\ University of Cartagena \\ 11pmargaritamontero@hotmail.com, ${ }^{2}$ diofanor3000@gmail.com, ${ }^{3}$ rmartelog@gmail.com
}

\begin{abstract}
The management of social projects is a strategy that seeks to improve the quality of life of disadvantaged populations, towards human well-being. The aim of this research was to analyse the management of social projects in vulnerable communities in the Department of Bolivar - Colombia, with respect to the components and objectives of the project "Red de Seguridad Alimentaria". The methodology was used under the paradigm of positivist, non-experimental, descriptive and field-based transectional research, with a sample of 277 families. As a data collection tool, a questionnaire was developed using the Likert response categories of 69 items, validated by seven experts in the field. The reliability of the instrument was determined by Cronbach's Alpha method presenting 0.94 reliability. The perceptions of the families surveyed regarding management approaches, basic functions, management components and scope of implementation of social projects, allow us to conclude that communities recognize the support of social project management in providing knowledge and methodologies for the implementation of social projects that contribute to reducing their large social deficit.
\end{abstract}

Keyword - Development, Management, Social Policies, Projects, Food Security Network.

\section{INTRODUCTION}

The global agenda increasingly presents issues of profound social content: minorities, ethnicities, gender, human rights, refugees, displaced persons, humanitarian crises, the fight against poverty, among others. The driving forces behind these social issues are the idea of equity, sustainability and participation, bearing in mind that the various social agents and the beneficiaries must be an active part of the policies, plans and programmes established to manage them together [1].

Thus, Ortiz et al. [1] affirm that "the management of social projects is the way in which the different political and social actors formulate and design policies that allow society to solve and confront social problems and disputes between actors in order to achieve their development", a condition that prevails in significant groups of the population, particularly in vulnerable communities, which due to circumstances of poverty, ethnicity, health status, age, gender or disability, find themselves in a situation of greater powerlessness to cope with life's problems and lack the necessary resources to meet their basic needs [2]. From these circumstances, the management of social projects emerges as strategies to improve the quality of life of disadvantaged populations, towards human well-being [1], [3], [4]; in the words of Arias [5], social project is a community project, a document in which ideas and actions to be developed in a period of time, with determined resources to satisfy needs and solve specific problems of a community with the active and protagonist participation of its members. In this way, it is inferred that the management of social projects relies on social programmes aimed at favouring vulnerable communities.

It should be noted that in Colombia, research has been carried out to identify social problems, especially those related to food and nutrition needs in the Department of Bolívar, which lead to the paradox that occurs in some municipalities where high levels of agricultural production coexist with poor access to food due to lack of money, confirming that food availability is not a sufficient condition for the eradication of hunger and malnutrition [6], [7]. The above demonstrates the need to include an equity analysis in the formulation of public policies aimed at guaranteeing food security and reducing poverty. In this sense, the management of social projects in Colombia is aimed at contributing to the strengthening of public policy on food and nutritional security at the regional level, especially in vulnerable communities. In this way, the social project entitled "Red de Seguridad Alimentaria (ReSA)" was born, whose purpose is to generate a change of attitude towards food production and consumption, taking advantage of the opportunities offered by the region, rescuing ancestral knowledge and practices, in order to motivate vulnerable communities to establish food production units for self-consumption, encourage healthy eating habits and practices in consumption, as well as promote the use of food and local products as part of a strategy to reduce hunger [8]. 
This research focused on the analysis of four key areas of social project management: (i) approach to project management, which covers public affairs, social development, stakeholder participation management, social policies, social innovation, public value creation, social inclusion and efficiency, ii) Basic functions of social project management, divided into five activities: planning, organization, motivation, personnel administration and control, iii) Components of the management of ReSA social projects, such as population motivation, dissemination and inputs, and iv) the scope of implementation of ReSA Social Projects.

\section{MATERIALS AND METHODS}

The methodology was used under the paradigm of positivist, non-experimental, descriptive and field-based transectional research. As a tool for data collection, a questionnaire was developed using the Likert response categories of 69 items with five response categories (very agreeable; agreed; neither agreed nor disagreeable; disagreed; strongly disagreed; strongly disagreeable), validated by seven experts in the field. The reliability of the instrument was determined by Cronbach's Alpha method with 0.94 reliability. The analysis of the variables was carried out under the theoretical criteria of social project management.

\section{A. Population and sample}

The population of this study consisted of 630 families from the city of Cartagena de Indias and 270 families from the municipality of Santa Rosa de Lima in the Department of Bolívar. Both groups of families add up to 900 families belonging to vulnerable communities in the department of Bolívar. In this sense, the representative and finite subset extracted from the accessible population is defined as the sample by Arias [5], using random or probabilistic sampling, at simple random. The population consisted of the universe under study with a sample of 277 vulnerable families.

\section{RESULTS AND DISCUSSIONS}

Regarding the perception with positive response categories of the 277 respondents on the indicators of social project management approaches supported by Ortiz [1] (Table 1), the results showed that 257 (92.77\%) of the families surveyed considered that the management of ReSA social projects presented a social development approach, i.e., that the management involved a body of knowledge and emerging practices that supported the intervention of social actors involved in solving food security problems that impacted the social development of this population, in this order of ideas, the participation of all actors on the one hand, and the adequate intervention to overcome the problems of food security that impede social development, on the other hand, were evident [1].

Table 1. Approaches to social project management

\begin{tabular}{|c|c|c|c|c|c|c|c|}
\hline Public & Development & Management & Political & Innovation & Value & Inclusion & Efficiency \\
\hline $92 \%$ & $93 \%$ & $87 \%$ & $89 \%$ & $86 \%$ & $86 \%$ & $87 \%$ & $89 \%$ \\
\hline
\end{tabular}

On the other hand, 255 of the families (92\%) admitted the presence of the equitable public approach in the management of ReSA social projects, which coincides with Ortiz (2013), who described the management of social projects as the management of public affairs in a society, limiting that the public is the meeting place between the common interests of the different social actors. In other words, it is the management of the common good; from this perspective it was observed that for this approach, the management of ReSA social projects was very close to the search for the so-called common good, since the collectivity (state, NGO, private sector) joined forces to carry out what is necessary for a minority that must be protected or safeguarded as a social commitment.

With regard to the focus on social policies, 246 families (89 \%) recognized it in the management of ReSA social projects, evidencing the achievement of community development and their participation in projects. This can be understood by considering that these projects correspond to an initiative based on the country's social policies; in this sense, it should be pointed out that Ortiz [1] establishes that the focus on social policies considers that the main function of the management of social projects is to generate, in a participatory manner, the social policies required by each context: national, regional or local. The social policy is based on all those activities that contribute to the health, nutrition, education, public assistance, social security and housing of the population, and also those that affect, in general, the redistribution and distribution of income and those aimed at building and conserving social capital.

In relation to the "efficient approach" according to Kliksberg, this has to do with optimizing the performance of state efforts and social actors in confronting the region's large social deficits, improving the functioning and results of investment in human and social capital. However, Ortiz [1] explains that the social deficit of a region implies that it is not possible to continue confronting the social issues on the part of the different actors in the same traditional and bureaucratic way. This involves a break with the ways in which social programs have been implemented and planned. In this order of ideas and according to the results obtained, 246 families (89\%) perceived that the management of social projects ReSA faced food insecurity problems not only with money 
(investment) but finding a timely solution to the various problems that arose during the implementation of the project to achieve the objectives set.

Regarding the "inclusion approach" in the management of ReSA social projects, 241 families (87\%) indicated that the management of ReSA social projects generated equitable conditions for a better quality of life, offered communities the development of their capacities and in an equitable way social services. This is in agreement with Pérez et al., [9], where the management of social projects is a mediation to make social development feasible, that the concept of management refers to the knowledge, qualities and skills to guide and manage the achievement of certain goals or objectives. In addition, the authors distinguish, the aims of the management of social projects are common with other concepts already seen: inclusion, equity, dignified living, capacity building and social development.

The results obtained in the indicator of the "problem and management approach" suggest that 241 of the families (87\%) perceived that the management of ReSA social projects achieved the objectives proposed in the program, which implemented the project with the least expenditure of human resources and in the shortest possible time. The above, taking into account that the problem and management approach qualifies the management of social projects according to Rey [10] as the set of applied knowledge that seeks to address the organizational and management problems of social policies and programs, fulfilling goals of effectiveness, efficiency, equity and sustainability.

According to Ortiz [1], the focus on "social innovation" in the management of social projects refers to participatory processes in which the communities themselves have the power and capacity to build models, systems and solutions to their daily problems with the help of science and technology, in which academics are not the exclusive center for the solution; in this sense, the results obtained in this research show that 238 of the families (86\%) evidenced the active participation of the following groups of people, who presented their contributions by means of new techniques of food preparation with ancestral products, as well as for the harvest of the same ones innovating in the systems of sowing, among others. This coincides with the author's point, that this type of innovation can be expressed in new or improved products, services, processes, organizational models, ways of developing programs and projects and in public policies. In this sense, it is inferred that $86 \%$ of the families surveyed perceived that the management of ReSA social projects built citizens for community development, allowed participatory processes giving power to communities, researched, investigated, searched, convened, experimented and proposed alternatives to find and/or achieve innovations.

Finally, the public value creation approach highlighted by Makote and Saavedra [4], defines the management of social projects as a field of action and knowledge strategically focused on promoting social development, guaranteeing the creation of public value through management, contributing to the reduction of poverty and inequality, strengthening the democratic state and full, inclusive and responsible citizenship. In this sense, according to the results of the research, it is evident that 238 (86\%) of the respondents identified that the management of ReSA social projects presented an approach to the "creation of public value" which contributed to poverty reduction, inequality to grant benefits and the strengthening of the democratic state in the vulnerable communities intervened in the Department of Bolívar in Colombia.

As for the basic functions of Social Project Management according to Fred [11], the organization plays a fundamental role by allowing a coordinated effort to define tasks and subordination relationships; in the same way, it includes all administrative activities that generate a structure of tasks and subordination relationships. In this sense, it was evidenced that 249 families (90\%) surveyed considered that the management of ReSA social projects made an effort to define and organize the pertinent tasks in order to achieve the project's objective and made it possible to make decisions for the participants of the communities (Table 2). Now, 246 families (89\%) identified planning in the management of ReSA social projects, evidencing that the communities benefiting from the project in the Department of Bolívar transformed their eating habits and had a change of attitude to improve their food security by taking advantage of the resources available for the implementation of the project and avoided the waste of ecological resources by encouraging the reuse of elements for the establishment of home-grown orchards, the use of natural resources and the use of natural resources, among others. This coincides with Fred [11] who affirms that within the functions of social project management, planning is the bridge between present and future for the transformation of dreams into achievements. The author also states that planning allows a company to gather the necessary resources and carry out tasks in the most efficient way to be seen as a useful and effective company.

Table 2. Basic Functions of Social Project Management

\begin{tabular}{|c|c|c|c|c|}
\hline Planning & Organization & Behavior & Administration & Control \\
\hline $89 \%$ & $90 \%$ & $88 \%$ & $86 \%$ & $87 \%$ \\
\hline
\end{tabular}


The role of motivational behavior in the management of ReSA social projects was perceived by 244 families (88\%), showing that it was characterized by its leadership for the development of positive attitudes and empowerment of communities, which was achieved through playful, motivational and practical activities during the project's execution; in this sense Fred [11] highlights the importance of this type of behaviour in the process of influencing people to achieve certain objectives and thus satisfy their needs, in this order of ideas the democratic behaviour of leaders generates positive attitudes strengthening empowerment. In the control function, $240(87 \%)$ of the families surveyed recognized this function in the management of ReSA social projects, which shows that it was able to ensure results related to improving the food security of the vulnerable populations intervened; results that coincide with what Fred [11] states relate control with those administrative activities aimed at ensuring that the results obtained are consistent with those projected.

Finally, 238 of the families (86 \%) consider that the management of ReSA social projects fulfilled the function of personnel administration, taking into account that it identified the weaknesses of human resources, trained them and delegated functions according to their strengths; in this sense, Fred [11] describes that personnel administration activities play an important role in the efforts to implement strategies, which is why it is important to identify the strengths and weaknesses in this area.

Motivation, one of the basic components of the ReSA Food Security Network project (Table 3), which included meetings with recreational, demonstrative and participatory activities that sought to generate and/or strengthen knowledge, skills and abilities conducive to motivating "attitude change" towards the production of food for self-consumption, strengthening traditional cultivation and the use and allocation of resources for food production and consumption, as well as the promotion of healthy eating habits, 269 families (97\% of those surveyed) considered the presence of this as a basic component in the management of ReSA social projects, since the project developed motivational meetings with recreational activities, implemented healthy eating habits, strengthened solidarity with techniques, developed a demonstration garden, held meetings of activities related to leadership and involved children as participants. Similarly, the component of inputs was represented by the delivery of seeds, vegetative material, minor species and other elements for the beginning of food production in the home garden, as well as the delivery of crockery, water filters, cutlery, cupboards, among others.

It should be noted that the management of the social project ReSA, guaranteed transport and logistics to deliver the inputs, in this sense, 269 of the families representing $97 \%$ of respondents recognized this component. On the other hand, it should be noted that the dissemination component consisted in the fact that each person who was part of the technical team carried a project logo on their clothing, caps, T-shirts, tops and aprons depending on the intervention area. In this sense, the results showed that the ReSA social project used banners, badges, aprons, cofias, caps, among others; in addition, it gave each family an apron and a cap, so that 266 of the families representing $96 \%$ perceived the component in question.

Table 3. Components of the management of social projects

\begin{tabular}{|c|c|c|}
\hline Motivation & Difussion & Supplies \\
\hline $97 \%$ & $96 \%$ & $97 \%$ \\
\hline
\end{tabular}

For the scope of the implementation of the Social Projects, it was observed that 272 (98\%) of the families (Table 4) admitted that the ReSA social project stimulated the return of the displaced population to their lands, by supporting projects to recover the productive capacity of the properties and benefits to small agricultural producers. Likewise, the objective related to the support was to support the productive project or main economic axis of the rural lands, promoting the sowing of products for self-consumption so that the resources generated by the main activity are not spent on buying the food that the land can give.

Table 4. Scope of implementation of Social Projects

\begin{tabular}{|c|c|c|c|c|c|}
\hline Prevention & Encouragement & Legitimation & Promotion & Alliances & Support \\
\hline $96 \%$ & $98 \%$ & $97 \%$ & $96 \%$ & $95 \%$ & $98 \%$ \\
\hline
\end{tabular}

On the other hand, 269 (97\%) of the families considered that the ReSA social project achieved the objective related to legitimisation, i. e. the fundamental right of every human being to food, because it promoted strategies to partially cover nutritional needs and involved the whole family group. In terms of the objective of the promotion, which is precisely to promote a change of attitude in small rural producers so that they produce to eat what the land can produce and in the general population to re-consume ancestral foods. It was observed that 266 (96\%) of the families affirmed that the ReSA social project achieved a change of attitude in the rural producers, promoting the sowing and consumption of native products such as eggplant among others. Likewise, the objective of the partnerships was to lead a set of alliances with other institutions interested in financially and technically supporting the program. This section shows that 263 families (95\%) perceived the achievement of 
this objective, which was evidenced in the achievement of financial support for the ReSA social project with other institutions to multiply resources, entering into cooperation agreements with international organizations and achieving alliances for the training of beneficiaries.

The foregoing confirmed the need for behavior in the management of social projects that fosters administrative action focused on relations of integration and cooperation, based on honesty, credibility, justice, humility and trust; guiding policies and organizational strategies whose objective is focused on satisfying the interests, needs and expectations of citizens and their community. It is also stated that in the management of social projects, public management requires certain very particular forms of action due to the characteristics of social services and the programmes themselves. This research made it possible to distinguish within the objectives of the management of social projects, on the one hand, the obtaining of results, so that the activities developed can have the expected impact on the target populations and the generation of value, which means satisfying the demands. On the other hand, ensure that programs achieve sustainability to develop selfconfidence in the target populations. With the achievement of these objectives, a citizenship is built that learns to exercise its rights and accept its responsibilities, especially in Latin America, where a large part of the population does not meet the minimum conditions to fully exercise its citizenship status. Participation in social programs becomes one of the main mechanisms for teaching and building citizenship.

\section{IV.CONCLUSION}

The social project ReSA promoted the planting of products for self-consumption, achieved the permanent income generated by self-consumption activities and managed to generate that families have more income to acquire their basic food basket. These results, confronted with the theoretical bases and the analysis and interpretation of the data, made it possible to determine the scope of the objectives of the Food Security Network project in vulnerable communities of the Department of Bolivar in Colombia, this being the last objective of the present research. With this, the communities recognized the support of social management in providing knowledge and methodologies for the implementation of social projects that contribute to reducing their large social deficit. In the same way, the families assured that the relationships between the actors of the project on responsibility helped to solve social situations in the pursuit of the common good. Likewise, they perceived the focus on social policies aimed at participation in projects, confronting the region's large social deficits and seeking favourable spaces for communities. In this complexity, the management of social projects was able to assist in the processes of organization, planning, motivation, administration and control in order to address and overcome possible contradictions for the implementation of social programs on vulnerable communities. Meanwhile, the families of the District of Bolívar considered that social management generated equitable conditions for a dignified quality of life, offered communities the development of their capacities and produced equitable social services for the communities.

\section{REFERENCES}

[1] A. Ortiz, “Conceptos de la gerencia social en América Latina,” Proy. Soc. Rev. Relac. laborales, vol. 16, no. 1, pp. 49-74, 2013.

[2] M. M. Cardoso, "Estudio de la vulnerabilidad socio-ambiental a través de un índice sintético. Caso de distritos bajo riesgo de inundación: Santa Fe, Recreo y Monte Vera, Provincia de Santa Fe, Argentina,” Cuad. Geogr., vol. 27, no. 48, pp. 1-8, 2017.

[3] C. M. Candamil and B. M. H. López, Los proyectos sociales, una herramienta de la gerencia social, 1st ed. Manizales, Caldas, 2004.

[4] K. Mokate and J. J. Saavedra, “Gerencia social: un enfoque integral para la gestión de políticas y programas sociales,” Wahington D.C, 2006.

[5] F. Arias, El proyecto de Investigación: Introducción a la metodología científica., 5nd ed. Caracas, Venezuela, 2012.

[6] R. Arrieta Flórez, A. García Martínez, and L. Leviller Guardo, Hambre y desnutrición en Bolívar: Un análisis desde el enfoque de la equidad y la seguridad alimentaria. Cartagena de Indias, 2010.

[7] L. Arboleda and B. Arroyave, "Inequidad, pobreza y desnutrición,” Nuevos Tiempos, vol. 12, no. 1, pp. 85-93, 2004.

[8] DPS, "Guía para la intervención de seguridad alimentaria y nutrición," Guía para la intervención de seguridad alimentaria y nutrición, 2014. [Online]. Available: http://www.dps.gov.co/pro/gd2/Paginas/Subdirección-de-Seguridad-Alimentaria-y-Nutrición.aspx.

[9] T. Pérez, M. Martínez, and A. Rodríguez, Gerencia social, integral e incluyente. Bogotá, Colombia: Universidad de la Salle, 2006.

[10] N. Rey de Marulanda, "Situación y problemática del gasto social en América Latina.," in Desafíos de la Gerencia Social en el Siglo XXI: La construcción de Sociedades Equitativas, 2002, pp. 14-24.

[11] F. R. David, Conceptos de administración estratégica, 9nd ed. Mexico: Editorial Pearson Education, 2003. 